\title{
The Russian Cinema at the Beginning of the New Millennium
}

\author{
By Christina Stojanova
}

Fall 2005 Issue of KINEMA

\section{THE RUSSIAN CINEMA AT THE BEGINNING OF THE NEW MILLENNIUM}

IN 1998, this journal published my article "The New Russian Cinema and the New Russian Society" (1) which examined the counter-productive impasse reached during the early post-Communist period by the thriving Russian auteur and the nascent experimental cinema. The mainstream cinema lovers became increasingly insensitive to serious art-house films and sought to satisfy their hunger for entertainment from whatever imported genre films were allowed on the chaotic film scene in the early 1990s.

Therefore this essay leaves out such significant, internationally acclaimed works of well established auteurs from the former Soviet Union such as A. Sokurov's Russian Ark (2002) and the third part of his dictators' trilogy about Japan's Emperor Hirohito (Sun, 2005); K. Muratova's Second Class Citizens (2001) and Chekhov's Motifs (2002); A. Rogozhkin's The Cuckoo (2002); V. Abdrashitov and A. Mindadze's Magnetic Storms (2003), as well as the latest Mindadze oeuvre, directed by A. Uchitel (Dream of Space, 2005). Neither will it include A. Balabanov's dark musing on love and death in a $19^{\text {th }}$ century leper colony in the Siberian taiga (River, 2002), nor dwell on the few powerful examples of young auteur cinema, made mostly by women directors such as L. Sidilova's With Love: Lilia (2002); G. Omarova's Schizo (2004); M. Razbezhkina's Harvest Time (2004); the highly controversial Four by A. Khrzanovsky (2005) and certainly not A.Zvyagintsev's celebrated debut The Return (2003) - winner of the Venice 2003 Golden Lion award. The reason for not dwelling on these films is that most of them are in North American distribution on DVD and / or video, and have been more or less widely discussed by the specialized and popular cinema press.

Here, the focus is on trends, themes and ideas, referred to briefly in my previous article as "the quest for the viewer." The genres under scrutiny are selected on the basis of their common occurrence amongst the films produced over the last five or six years so that their discussion would allow for a broader cultural perspective on the complex interplay between new Russian cinema and the post-Communist, post-Soviet society and politics.

First this essay looks into the renaissance of melodrama in order to elucidate aspects of the politics of popular genres in general, leading to attempts at their post-Communist revival as the "new creative rhetoric of moral law." (2) Russian popular cinema's quest for its lost viewers evolves against the backdrop of unprecedented crises resulting from the post-Communist rupture of social and moral values. In the wake of what Maurice Blanchot calls, with regard to the French Revolution, the "prodigious suspension" (3) of all other imperatives, when, with the collapse of the totalitarian regime, the "law - social, moral, natural, rhetorical - fell silent," the popular genres tend to demonstrate "that it is still possible to find and show the operation of basic ethical imperatives.... That they can be staged indeed 'proves' that they exist." (4) The fascinating importance of this study is, in my view, "to define, in conflictual opposition," the social, ideological and aesthetic play (5) of the basic ethical imperatives. Therefore I offer some insights into an entirely new development in Russian cinema - that of the purely entertaining - and melodramatic by definition - blockbuster film, which challenges seriously the supremacy of its American counterpart on the Russian screen.

Second, an intriguing recent phenomenon is examined: the revival of the nationalist Russian movie, which had demonstrated remarkable resilience throughout the history of Soviet cinema. Its current apparition is alluded to as "Putin's cinema," and features, quite understandably, mostly military and KGB men engaged in heroic acts either in WWII combat operations or in peacetime, thus safely avoiding any post-modern moral ambiguities and political controversies, plaguing the army and the "special units" (i.e., the secret services) like corruption scandals, the Chechen wars, the revival of chauvinism and Stalinism, etc.

The concluding section discusses the latest developments of the new, post-Communist genre, which I call the Mafiosi thriller ${ }^{(6)}$ - a curious, cross-cultural hybrid between American genre formulas and Russian artistic sensitivity, and a controversial product of (anti) Americanization impetus - bearing in mind Susan Suleiman's contention that "naming a genre is already half the interpretation." (7) The cinematic representation of the 
New Russians has evolved over the last years in two directions - that of the melodramatic, soap opera glorification and that of bitingly grotesque or Neo-realistic condemnation of the Mafiosi.

\section{Melodrama}

Russian film scholar Irina Shilova points out a few key reasons for the decline of melodrama under Communism, and by extension, of popular genres in general. In her view, "sentimental education" in handling emotional excess was never high on the agenda of Russian filmmakers, as it "somehow escaped their didactic preoccupations with enlightenment and education, with 'high' art as opposed to the 'low' art of entertainment." (8)

The troubles with melodrama however continued well beyond the period of ideological restrictions due to another major hurdle: the prolonged absence of nominal consensus as to what the basic values of postCommunist society are: what is socially acceptable and what is not; what is prestigious and what is not; essentially, what is good and what is evil. Neo-liberalism provided ideological justification for the postCommunist transition in the public sphere, but failed miserably in the private. Unlike its $19^{\text {th }}$ Century ancestor, bourgeois capitalism, which burst into the social and cultural scene with its particular set of ethical values, staged in genres like melodrama, post-Communist Neo-liberalism refused to provide evidence for its viability in other than macro-economic terms. Apart from some vaguely implied miraculous interdependence between Western-style affluence, market economy and democratization, no justification was offered in either ethical or aesthetic terms for the pains of transition. The emotional void, once again, has been left open to foreign products - American and Latin American soap operas. Therefore, despite what Thomas Elsaesser defines as melodrama's general tendency - to benefit from periods of "intense social and ideological crisis," (9) it was not before well into the 1990s that the first successful Russian melodramas began to appear.

Nikita Mikhalkov's Oscar-winning Burnt By the Sun (1994) was among the first to break the melodramatic impasse by tapping into the emotional excess, released with multitude of repressed memories and images from Russia's recent and distant past. Thus the existence of basic ethical imperatives was first demonstrated in staging melodramatic stories in period settings. The simple story about a day in the life of a 1917-1922 Civil War hero, victimized by Stalin's purges from the 1930s activated a powerful national sentiment and, within the confines of a love triangle, dealt with the grave public issues of loyalties and betrayal. Mikhalkov encored his successful attempt to resuscitate the melodramatic genre with The Barber of Siberia (1999), a rendition of yet another tragic love story, exorcising another set of deeply seated national complexes. The perennial tension between Western influence, represented by an American adventuress, and the Russian tradition, epitomized by a young Russian cadet was projected on the lavish, albeit treacherous backdrop of imperial Russia.

If Elsaesser is right when claiming that "melodrama as a popular cultural form takes ... a social crisis and mediates it within a private context," (10) then Lidia Bobrova's Granny (Baboussia, Russia-France, 2003 ) is indeed an excellent example of mediating the current social and moral turmoil in Russia within the confines of a family. It also demonstrates the filmmakers' growing confidence in handling emotional excess in contemporary setting. What is more, the film underscored the consolidation of the post-Communist value system around growing consensus that the source of all evil is the post-Communist-post-Soviet change, while propagating a nostalgic return to the good old atavistic past - that of Brezhnev's stagnation in the 1970s. Granny is liable to provoke "ecstatic woe, sobs and tears" featuring the grim final voyage of its elderly heroine, who after being rejected by all of her children, proceeds to her predictable suicide of exposure. The contemporary wintery episodes are juxtaposed with reminiscences of beautiful sunny days in the 70s when everyone lived in harmony. Through a representative selection of the children's social status, Bobrova pushes the metaphor even further, heavily implying that Baboussia is no other than Mother Russia, who has been kicked out in the cold by her ungrateful, nouveau riches children and is dying, desperate with her inability to help the really deserving ones - the refugees from Chechnya.

Over the last couple of years, melodrama is taking an increasingly important place not so much as a genre stricto senso but as a general artistic mode and a worldview, so to speak, often blending in traditional Russian sentimentality, Eastern Orthodox mysticism and urban mythology. Thus Yelena Nikolayeva's hit Popsa (2005) - a story of a young girl's rise from a country bumpkin to a pop star in the ruthless world of Moscow showbiz - taps into the "star is born" conventions of the genre. But instead of relying on musical 
numbers as a Hollywood film would, Popsa plays up its social sentimentalism and criticism.

The girl and her formidable female entrepreneur bond in a mysterious Russian manner against the odds of the world of the rich and the powerful (men). Night Watch (Timur Bekmambetov, 2004) is also openly designed as a commercial vehicle, but thrives not so much on the pure entertainment provided by head-spinning special effects as on the charged confrontation between Good and Evil, i.e., between the Night and the Day Watches, whose not-so-subtle likeness to familiar social circles (unemployed intelligentsia understandably are cast as Day Watches, and New Russian thugs as the Night ones) is externalized in the excessive psychic states of its characters. The record admissions to this truly Russian blockbuster (called also the "Russian Matrix") has prompted the making of Night Watch 2 and 3, and Hollywood is rumoured as being interested in buying the remake rights.

\section{"Putin's Cinema"}

The Russian melodramatic imagination has however found a most suitable ground in the resuscitation of the expensive genre of the nationalist military movie of old. Over the last couple of years two powerful war films were made by directors born in the 1960s, seizing the chance to share their version of WWII events that have formed the Soviet and Russian national identity over the last sixty years. For his film The Star (2002), officially labelled "Putin's favourite film," Nikolai Lebedev has chosen to remake an extremely popular film under the same title made in 1950 by A. Ivanov and seen by more than 30 million viewers! Set in 1944, it tells a simple story of a Red army intelligence squad unit behind enemy lines. "Star" is the code word, but it also refers to the red star the Soviet soldiers used to wear on their caps, as well as to the Red Star towering above the Kremlin before disappearing along with other symbols of the Soviet era. And when the "star" vanishes from the radio waves, the beautiful operator Katya, the only woman in the film, realizes that her beau, the brave lieutenant, has died heroically along with his six scouts but not before informing the headquarters about the imminent enemy offensive. The film follows its prototype's plot verbatim, but skilfully replaces its woodenly euphemistic Socialist Realist didacticism with excessive, post-modern violence and open emotionality, evoking the sentimental-melodramatic mood of such classics of post-Stalinist humanism as the well-known in the West M. Kalatozov's The Cranes Are Flying (1957) and G. Chukhraj's Ballad of a Soldier (1959).

World War II, called also the Great Patriotic War, was arguably the last just war the Russians waged. According to the official historiography, it allegedly united the whole population for sacrifices in the name of Mother Russia and Victory in an unprecedented (and probably unrepeatable) manner. Tapping into this source of national pride is understandable in Putin's Russia, where the very idea of statehood in the traditional (and authoritarian) sense is challenged from all sides: by the young who demand an open democratic society in order to prosper; by the old, whose dreams of stability hark back to Brezhnev's totalitarian state; by the ethnic minorities, who push relentlessly and violently for independence; and last but not least by the New Russians, the so-called oligarch or tycoons, who demand a free hand in marshalling their enormous wealth not only economically, but also politically.

Another WWII film, Dmitri Meskhiyev's Our Own (aka Us, 2004) was literally showered with all national awards thus proving that the success of The Star was not an isolated case. It also proved that a Putin's movie, like his politics, is anything but simplistically panegyrised history. In a manner unlike any Soviet or Russian film before, Our Own casts light on the inner life of a country, engulfed by the chaos of 1941, the first war year. It shows mercilessly the conflicts in a village, where three Red Army soldiers - a Jewish intellectualpolitical commissar, a Russian secret service man (or chekist ${ }^{(11)}$ ) and a Ukrainian sniper - hide from German imprisonment. The village is a microcosm of the "unpatriotic" war, waged in the occupied territories, where the fate of the Commissar and the Chekist hang in the fragile balance, determined by collaborators, traitors, opportunists, sceptics and pragmatic peasants, but most importantly - by the sniper's father, who happens to be the village mayor. The father, portrayed with artistic magnificence by the leading Ukrainian actor Bogdan Stupka, is the film's centre and true revelation. Despite his obviously deep hatred of the Soviet regime for having imposed double, social and national, yoke on his village, he feeds them, takes care of the ailing Commissar and, putting at stake the lives of his beloved daughters, ultimately lets them free. Not that he is persuaded by the Chekist's final breakdown and tearful plea that "we all are family." He lets his rifle down in the name of the only goal that could possibly bring together a Ukrainian kulak (derogatory for rich peasant) and a Russian Chekist - the fight for the fatherland. The simple humanist message of this superb 
war film acquires a new meaning in the light of Russia's current difficulties and Putin's repeated attempts to persuade his compatriots to put aside their social and ethnic differences in the name of the ailing fatherland.

Pavel Chukhrai's A Driver for Vera (2004) is the newest contribution to Putin's cinema. The film is situated in the relatively relaxed 1960s, and reveals little known tensions between the military and the KGB. It tells the story of a Soviet marine general of Ukrainian origin used as a scapegoat in an investigation of a nuclear submarine disaster in the wake of the Cuban missile crisis, which the Soviets tried to conceal but the Americans demanded an explanation for. At the same time the general is hard pressed to dissuade his spoiled handicapped daughter Vera from aborting an unwanted pregnancy. He brings to Crimea a young, good-looking officer from Moscow to replace his former driver with the hope that he might get to like and marry Vera. Featuring again Stupka as a powerful man, humbled by his child's predicament, the film offers a superb portrait of the dark sides of life at the top, hidden in the sun-lit seaside villas. The driver does get attracted to Vera or rather to her newly born fatherless child, but the political intrigue thickens when the general's private aide and KGB man on site tries to recruit him. After having witnessed the general's assassination and Vera's murder by the KGB thugs, he hides with the baby in a ravine in what seems a hopeless attempt to divert a certain death. It is his former colleague, the aide, who discovers them, but in a surprising change of heart, the man decides not to report them thus saving their lives. Significantly, the part of the aide is played "against the grain" by Andrei Panin who made his name as the fetish villain of Mafiosi thrillers.

Such attempts at exposure of dark secrets from the Soviet history only to highlight model heroes and positive gestures of forgiveness and self-sacrifice as expression of the proverbial Russian soul, no matter how isolated and inefficient against the backdrop of total fear and betrayal, is the very stuff Putin's films are made of. These films understandably appeal to a creeping rehabilitation of the formidable KGB officers and the Party Commissars, associated more often than not with pure evil in the Russian collective unconscious. If Russia is to survive in the new millennium, the subtle message goes, people have to learn to empathise even with the bad boys for "we all are family." All the more significant that the KGB is Putin's native organization and he genuinely believes that only its strictly groomed cadre could save Russia from plunging into chaos.

\section{In a Way of Conclusion: the Mafiosi Thriller}

It seems however that no amount of artistry and "positive" role models could divert the viewers' attention from the aggressive and multiple apparitions of the Mafiosi thriller, fixated on the life of the New Russians. As the best examples of the new genre demonstrated in the mid-nineties, it had a propensity to bring forth the negative aspects of society and its mores. The Mafiosi thriller appeared in the troubled early 1990s as a mixture of elements, borrowed from Hollywood gangster film, noir thrillers and the vigilante movie, and its formulaic content could be summarized as the struggle of the lonely hero to restore justice against the villains - mostly former members of the Communist secret services turned Mafiosi. One of the latest typical Mafiosi thrillers is Sisters (2001), Sergei Bodrov Jr.'s only film. Like its most prominent predecessor, A. Balabanov's Brother (1997), it owes its popularity to the carefully observed balance between appreciation and condemnation, between myth and reality. But unlike its predecessors, Sisters offers a balanced gender representation by following the growing affection between two estranged sisters, caught between Mafiosi settling their accounts, who become the film's only "rational and moral agents," (12) capable of differentiating between Good and Evil.

The genre's evolution has been consistent with the escalating social pessimism, emphasized here via the director's cameo appearance. This innocent, narcissistic gesture links Bodrov Jr.'s screen persona as the good Mafioso-cum-(possible)-saviour with the Brother films, where he played the star role, suggesting that while law and order in Russia are in ever-shorter supply, his vigilante heroes and the entire Mafiosi genre will continue to be very much in demand. ${ }^{(13)}$

The newest genre developments have absorbed new aesthetic influences, but have remained ethically ambivalent as to "whether to condemn the Mafiosi as greedy and ruthless villains killing mainly for hire, or to represent them as knights of a sort, or contemporary Robin Hoods." (14)

This ambiguity is best illustrated by the extremely popular works of the young director Aleksei Sidorov: the TV mini series Brigada (Law of the Lawless, 2002) and the blockbuster Shadow Boxing (2005). While romanticizing the ten year-old bond of four childhood friends, the director fails to change his stance with 
the collapse of the Soviet Union, when his characters drastically change into big Mafia bosses ever deeper involved in murderous biznes and intricate emotional affairs (Brigada). In his new film he goes to the other extreme to create a model positive hero, who, like the protagonist from Brother, succeeds single-handedly in beating the Mafiosi at their game. Despite the short time imprisonment (!), he gets the girl and what is more, gets his international boxing career back on track, thus preparing the stage for Shadow Boxing 2.

Pavel Lungin's Tycoon (2002) offers yet another romanticized view of the Mafia, very close to that of Brigada, minus its youthful vigour and charm. It, too, features a group of friends, who seize upon the seemingly limitless biznes opportunities in the early 1990s, and focuses on their eventual betrayal or alienation from the one, destined to become the oligarch (or tycoon). However, even Lungin's Midas touch in analyzing the social and national(-istic) idiosyncrasies of post-Soviet Russia could not save Tycoon from being too literal and boring tribute to the life and times of Boris Berezovsky (one among the most powerful of Russia's thirty or so oligarchs), especially after his scandalous extradition by Putin to England just before the film was released.

Two films from the other end of the spectrum warrant special attention. The first is Killer (1998), an early attempt of the Kazakhstan director Darezhan Omirbayev to deconstruct the genre via merciless Neorealist examination of the social and psychological desperation, which forces honest people into serving post-Communist Mafias. There is nothing charismatic or romantic in the senseless end of a quiet young driver, blackmailed into killing an outspoken journalist and then shot to death as a precaution, leaving his young wife and sick baby in utter destitution. Instead of glamour, car chasing, and endless lavish parties with gorgeous blonds, we are shown the dire realities of post-Soviet life: unemployment, poverty, alcoholism, and ruthless corruption and lawlessness.

Understandably, Russian and post-Soviet viewers are shunning away from such films whose bleakness hits so close to home, calling them chernukha (or blackness). Therefore Balabanov, one of the most original and controversial Russian filmmakers nowadays and founding father of the Mafiosi thriller, has chosen another way to deconstruct and even close off the genre, at least as a vehicle of glamorizing the Mafiosi. Zhmurki (Blind Man's Buff, 2005) is a hilarious pastiche of 1990s Russian-Mafia movies, and is structured as a comic-book illustration to a high-school lesson on the "initial accumulation of capital." Balabanov's callous representation of the intellectual and educational "merits" of the present-day tycoons heavily quote Guy Ritchie's dim-witted gangsters and farcical plots, while the description of their biznes methods and political skills make good use of Tarantino's piles of corpses and rivers of blood. In this biting testimony on the present state of Russia's affairs the director is joined by a star cast, including N. Mikhalkov, A. Panin, I. Makovetsky, R. Litvinova, who have apparently agreed to deconstruct their own popular images as a form of a civic duty, in the hopes that their cutting satire could somehow help the ailing Russian society. This noble concern tends to be increasingly mired in the unprecedented number of adaptations of Russian classics made into TV mini-series: Bulgakov's The Master and Margarita, Tolstoy's Anna Karenina, Dostoevsky's Idiot and The Karamazov Brothers, Gogol's Dead Souls, Pasternak's Dr. Zhivago, to name but a few. Apparently, many a talented Russian directors have their work cut out until the end of the millennium's first decade. The serene middle ground between the auteur and the popular cinema is unquestionably a comfortable (and

lucrative) alternative to the artistic challenges of the "high" art and the political and social controversies of the "low" genres. In a few years' time, this aspect of Russian cinema will likely be ripe for another article.

\section{Notes}

1. Kinema No.10 (Fall 1998), 5-18.

2. Peter Brook, The Melodramatic Imagination (New Haven and London: Yale University Press, 1976), p. 201.

3. Maurice Blanchot, "L'Inconvenance majeure," in Sade, Français encore un effort si vous voulez être républicains, Collectio Libertés (Paris: J.-J. Pauvert, 1965), in Peter Brook, ibid.

4. Peter Brook, ibid.

5. Peter Brook, ibid. 
6. Christina Stojanova. 1997. "Le film de genre américain dans le cinema post-communiste: 'le Mafiosi Thriller," in Ciné-bulles 17, No.2 (Été) Summer 1998, 38-43.

7. Susan R. Suleiman. 1993. Authoritarian Fictions (Princeton University Press: Princeton, NJ), p. 4.

8. Irina M. Shilova, "Emotions as the Source of a Genre", trans. Christina Stojanova, in Kinovedcheskie Zapiski 11 (1991), 67-71.

9. Thomas Elsaesser, "Tales of Sound and Fury", in Christine Gledhill (ed.), Home Is Where the Heart Is (London: BFI, 1987), p. 45.

10. Ibid, p. 47.

11. From Cheka, the initials of the Russian words for "extraordinary commission,"one of the early abbreviations of the Soviet Secret Police.

12. Václav Havel. 1978. "The Power of the Powerless" in The Power of the Powerless, Edited by John Keane (Hutchinson: London), p. 65.

13. Unfortunately, S. Bodrov, Jr. perished in the first days of shooting of his second film, The Connector (Svyaznoi, Russia, 2002) where, building further on his screen persona, he was to play the leading role of a discharged army officer with amputated legs, who has dedicated his life to fighting the Mafiosi.

14. "Le film de genre américain dans le cinema post-communiste: 'le Mafiosi Thriller'", in Ciné-bulles 17, No.2 (Été) Summer 1998, 38-43.

\section{Author Information}

Christina STOJANOVA teaches at the Department of Media Production and Studies at the University of Regina, Canada. She has contributed to Cine-bulles, KinoKultura, and the Montreal Gazette. Her publications include chapters in Berlin Culturescapes, Making it Like a Man: Canadian Masculinities, Eastern European Cinema, Traditions in World Cinema, Horror International, Alternative Europe and Cinema and Globalization. 